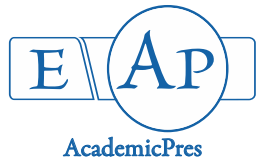

\title{
Effects of Growth Regulators and Type-Variety of Oil Palm (Elaeis guineensis Jacq.) on Direct Organogenesis
}

\author{
Chibuzo N.C. NWAOGUALA ${ }^{1 *}$, Hakeem O. SHITTU² \\ ${ }^{1}$ University of Benin, Faculty of Agriculture, Department of Crop Science, Ugbowo Campus, P.M.B. 1154 Benin City, Edo State, \\ Nigeria; chibuzo.nwaoguala@uniben.edu (*orresponding author) \\ ${ }^{2}$ University of Benin, Faculty of Life Sciences, Department of Plant Biology and Biotechnology, P.M.B. 1154 Benin City, Edo State, \\ Nigeria; olalekan.shittu@uniben.edu
}

\begin{abstract}
The in vitro organogenesis of embryos of type-variety ('Albescens', 'Nigrescens', 'Virescens' and 'Idolatrica') of the oil palm (Elaeis guineensis Jacq.) with growth regulators was studied. Murashige and Skoog (MS) medium, supplemented with nine treatment concentrations of Naphthalene acetic acid (NAA) and 6-Benzylaminopurine (BAP), alone and in combinations, was used to initiate embryo cultures of the type-variety. Data were collected on time of root production, root length, plant height, number of leaves and number of roots. The results obtained indicated that there were swelling and expansion of the matured zygotic explants in cultures within 7 and 14 days after culture initiation (DCI). Time of root production did not vary significantly among type-variety, but differed significantly $(\mathrm{p}<0.001)$ due to growth regulators, whereas their interaction effect was non-significant. Root length and plantlet height significantly varied $(\mathrm{p}<0.05)$ due to type-variety and growth regulators, as well as their interaction. There were no significant variations among type-variety on number of leaves and roots produced at $84 \mathrm{DCI}$, but there was significant $(\mathrm{p}<0.05)$ variations on number of leaves and non-significant variance on number of roots due to growth regulators. The type-variety combined with growth regulators effects on number of leaves and roots were not significant. In the present study, the responses of the various type-variety in the regeneration of plantlets in vitro varied with respect to media supplementation and that low concentration of NAA and BAP, alone and in different combinations, favoured root, leaf and plantlet production in MS medium.
\end{abstract}

Keywords: dormancy; embryo; embryogenesis; germination; in vitro; seed

\section{Introduction}

Oil palm (Elaeis guineensis Jacq), a native of West Africa is a perennial monocot and monoecious plant that has its male and female flowers occurring separately on the same plant, usually in distinct male and female inflorescence (Corley and Tinker, 2003). The palm belongs to the kingdom Plantae, order Aracales, family Arecaceae, subfamily Arecoideae, tribe Cocoeae, genus Elaeis and species guineensis (Corley and Tinker, 2003). Generally, the African oil palm, Elaeis guineensis Jacq. received its name from Nicolas Jacquin (Bailey, 1933). The generic name Elaeis was derived from the Greek word "Elaion", meaning oil. The genus has three species: E. odora, E. oleifera and $E$. guineensis. At present, only E. guineensis is being exploited for oil production. There are basic varieties of E. guineensis which include 'Dura', 'Pisifera' and 'Tenera' (Opeke, 1992). Also, oil palm can be classified based on fruit colour into
'Albescens', 'Virescens', 'Nigrescens' and 'Idolatrica' (Seng et al., 2007).

Oil palm can be propagated by seeds, but this method of propagation has been a major challenge in the oil palm industry over the years (Rival, 2000). Oil palm seed or nut is always dormant and slow to germinate, except certain specific temperature, oxygen and moisture requirements are met. Seed dormancy in the oil palm is caused by two physical barriers: the hard shell (endocarp) and operculum. If these physical barriers are removed, the oil palm seed germinates easily (Ndon, 2006). Any method that can break dormancy and induce rapid germination serves as better alternative, which in vitro culture technique offers.

In vitro culture (tissue culture) refers to the culture of living materials such as seeds, embryos, organs, tissues, cells and protoplasts on nutrient media under sterile conditions (Pierik, 1984). Presently, the most frequently used in vitro cultures are callus, cell suspension, protoplast and organ (embryo and meristem) cultures. These cultures can be used to regenerate whole plant. There are two pathways by which 
252

plant can be regenerated in vitro: through somatic embryogenesis and organogenesis (Trejgell et al., 1998). Embryogenesis refers to the production of somatic embryos, which germinate in culture to regenerate whole plants, while organogenesis refers to the production of plant organs (roots, shoots and leaves) that may arise directly from the meristem or indirectly from undifferentiated cell masses known as callus (Hussain et al., 2011). Plant regeneration via direct organogenesis seems to be better as compared to indirect regeneration. This is because plant regenerated through the intermediary of the callus may differ from the mother plants (Trejgell et al., 1998). The success of a plant tissue culture procedure is dependent on certain factors which include: growth media, environmental factors, explant source and genetics (Shittu et al., 2015). Murashige and Skoog's (MS) medium is commonly used for the in vitro cultures of oil palm zygotic embryos, although variation may occur due to the type and concentration of growth regulator used (Thawaro and Te-chato, 2010; Shittu and Mgbeze, 2012). Plant growth regulators are organic compounds, natural or synthetic, which when exogenously applied in small quantities, have similar actions to those of plant hormones (Caldas et al., 1990). Plant tissue cultures are regulated by the interaction of environmental signals and plant growth regulators such as auxin and cytokinin.

In vitro culture technique remains the only means of micropropagation of oil palm, as its biological characteristics do not allow for vegetative propagation by conventional means. Numerous in vitro studies have been carried out on the different fruit forms ('Dura', 'Pisifera' and 'Tenera') of Elaeis guineensis (Odewale, 1983; Nwankwo and Krikorian, 1983; Shittu and Mgbeze, 2012; Mgbeze and Iserhienrhien, 2013; Shittu et al., 2013; Odenore et al., 2015). However on the basis of pigmentation that discriminate the typevariety ('Albescens', 'Nigrescens', 'Virescens' and 'Idolatrica'), there is handful amount of research focus on these type-variety.

The objective of the study was to investigate the effects of type-variety and MS media supplementation with different combinations of plant growth regulators (Naphthalene acetic acid [NAA] and 6-Benzyl amino purine $[\mathrm{BAP}])$ on direct organogenesis of Elaeis guineensis embryos in vitro.

\section{Materials and Methods}

\section{Plant materialsused}

The study was carried out at the Tissue Culture Laboratory of the Nigeria Institute for Oil Palm Research (NIFOR), Benin City, Edo State. Matured seeds of the type-variety of Elaeis guineensis ('Albescens', 'Nigrescens', 'Virescens' and 'Idolatrica') were obtained from the Plant Breeding Division of the Institute.

\section{Media preparation}

Murashige and Skoog (MS) medium, which consists of macro nutrients, micro nutrients, Iron, vitamins, Casein hydrolysate and other supplements was used for the study. The medium was prepared based on the laboratory protocol (Murashige and Skoog, 1962) and dispensed into nine
Magenta bottles. Specific volume of growth regulators (NAA or/and BAP), each at concentration of $0.0,0.05$ or 0.1 , singly or in combinations was pipetted to the various Magenta bottles which served as various treatments. The $\mathrm{pH}$ of each medium was adjusted to 5.8 using $0.1 \mathrm{~N} \mathrm{HCl}$ or $0.1 \mathrm{~N} \mathrm{NaOH}$. To each treatment, $1.3 \mathrm{~g} / 160 \mathrm{ml}$ of agar and $0.32 \mathrm{~g} / 160 \mathrm{ml}$ of activated charcoal were added and thoroughly mixed together. The media were melted in a microwave and dispensed into test tubes which served as replicates. The test tubes were tightly covered with aluminum foil and sterilized along with forceps, petri dishes and foil papers by autoclaving at $121^{\circ} \mathrm{C}, 15$ psi for 30 minutes. After autoclaving, the media were taken to the cooling room and allowed to cool.

\section{Sterilization of explants and establishment of in vitro} embryo cultures

The Laminar flow chamber used for inoculation was sterilized by spraying and wiping with ethanol. The palm kernels were sterilized by placing them in a beaker and $70 \%$ ethanol was added and shaken for 15 minutes. The ethanol was drained and rinsed 3 successive times with sterile water. An aliquot of $3.5 \%$ of sodium hypochlorite $(\mathrm{NaOCl})$ was added to the explants to sterilize them for another 15 minutes. The sterilizing agent was drained and rinsed 3 successive times with sterile water. Embryos of the oil palm type-variety seeds were excised aseptically from the endocarp, using sterile surgical blade and placed in Petri dishes. The excised embryos were sterilized using $0.1 \%$ of sodium hypochlorite $(\mathrm{NaOCl})$ drained immediately and rinsed with sterile water. Inoculation of explants was done using forceps to collect the embryos and placing them in the MS media. Flaming of the forceps was done after each inoculation process with ethanol lamp.

\section{Incubation of embryo cultures and data collection}

After the inoculation, the embryos cultures were incubated in the dark growth room at $25 \pm 2{ }^{\circ} \mathrm{C}, 50$ to $60 \%$ relative humidity until emergence of shoot or root. The plantlets were transferred to the light growth room at $25 \pm$ $2{ }^{\circ} \mathrm{C}, 50$ to $60 \%$ relative humidity and 16 hours of photoperiod (light and dark regime was created artificially in growth room). Subcultures were carried out on a fourweekly interval. Data on time of root production, root length at different time intervals, plantlet height, number of leaves and number of roots were collected and subjected to statistical analysis.

\section{Experimental design}

The experimental design used for this study was a $4 \times 9$ factorial arrangement in completely randomized design laid out in four replicates with four types-variety of oil palm and nine treatment combinations viz: $0 \mathrm{NAA}+0 \mathrm{BAP}(\mathrm{mg} / \mathrm{l})$; $0.05 \mathrm{NAA}+0 \mathrm{BAP}(\mathrm{mg} / \mathrm{l}) ; 0.1 \mathrm{NAA}+0 \mathrm{BAP}(\mathrm{mg} / \mathrm{l}) ; 0$ $\mathrm{NAA}+0.05 \mathrm{BAP}(\mathrm{mg} / \mathrm{l}) ; 0.05 \mathrm{NAA}+0.05 \mathrm{BAP}(\mathrm{mg} / \mathrm{l})$; $0.1 \mathrm{NAA}+0.05 \mathrm{BAP}(\mathrm{mg} / \mathrm{l}) ; 0 \mathrm{NAA}+0.1 \mathrm{BAP}(\mathrm{mg} / \mathrm{l})$; $0.05 \mathrm{NAA}+0.1 \mathrm{BAP}(\mathrm{mg} / \mathrm{l})$ and $0.1 \mathrm{NAA}+0.1 \mathrm{BAP}$ $(\mathrm{mg} / \mathrm{l})$ of plant growth regulators set up to determine the effect of NAA and BAP in three concentrations $(0 \mathrm{mg} / \mathrm{l}$, $0.05 \mathrm{mg} / \mathrm{l}$ and $0.1 \mathrm{mg} / \mathrm{l})$ alone and in combinations on the organogenesis of oil palm seed. 


\section{Statistical analysis of data}

The Statistical tool used for the analysis was Genstat statistical software (12th edition). Measurable variables were tested for significance with two-way analysis of variance (ANOVA) procedure for a completely randomized design. The treatment means comparisons and all pair wise comparisons were done using Student Newman Keul's Test (SNKT) at 0.05 probability level.

\section{Results}

The response of embryos of type-variety of oil palm to various combinations of growth regulators with respect to time of root production and root length, 14, 21, 28 and 35 days after culture initiation (DCI) is presented in Table 1. Swelling and expansion of the matured zygotic embryo explants in cultures occurred within 5-7 days, which was followed by the formation of haustorium, approximately 7 10 days after culture initiation (DCI). The haustorium enlarged and began to turn to green and finally root and shoot emergence were observed within 7 and $14 \mathrm{DCI}$, respectively. Time of root production did not vary significantly among the type-variety, but differed significantly $(\mathrm{p}<0.001)$ due to growth regulators. Typevariety $\times$ growth regulators variance was also not significant. The mean value for the earliest of time of root production (7.31 DCI) was obtained in the medium supplemented with $0 \mathrm{NAA}+0$ BAP $(\mathrm{mg} / \mathrm{l})$ and $0 \mathrm{NAA}+0.05 \mathrm{BAP}$ $(\mathrm{mg} / \mathrm{l})$, while the latest response in time of root production (8.88 DCI) was obtained in medium having $0.1 \mathrm{NAA}+0.1$ BAP $(\mathrm{mg} / \mathrm{l})$. Root length did not significantly differ among the type-variety at $14 \mathrm{DCI}$, but significantly varied $(\mathrm{p}<$ 0.05 ) at 21, 28 and 35 DCI. Type-variety 'Nigrescens' had the longest root length at 21, 28 and $35 \mathrm{DCI}$ and the root lengths at these stages were significantly $(\mathrm{p}<0.05)$ longer than those of 'Albescens' and 'Idolatrica' but not significantly longer than that of 'Virescens'. The root length of 'Virescens' however did not significantly differ from the other three type-varieties. While there were no significant differences in root length due growth regulators at 14, 21 and $28 \mathrm{DCI}$, significant variance was obtained for root length at 35 days after embryo inoculation in the medium. The longest root $(4.78 \mathrm{~cm})$ was obtained at $35 \mathrm{DCI}$ from the medium containing $0 \mathrm{NAA}+0.05 \mathrm{BAP}(\mathrm{mg} / \mathrm{l})$ and they were significantly longer than the roots from medium supplemented with $0.1 \mathrm{NAA}+0.01 \mathrm{BAP}(\mathrm{mg} / \mathrm{l}(4.19 \mathrm{~cm})$ and those containing $0 \mathrm{NAA}+0.01 \mathrm{BAP}(\mathrm{mg} / \mathrm{l})(4.18 \mathrm{~cm})$. The other six treatments did not significantly vary in root length from one another.

The interaction effects between type-variety $x$ growth regulators with respect to root length which varied significantly only at $35 \mathrm{DCI}$ is presented in Fig. 1 . The best interaction effect was 'Virescens' in $0 \mathrm{NAA}+0.05 \mathrm{BAP}$ (mg/l), followed by 'Nigrescens' in $0.05 \mathrm{NAA}+0.1 \mathrm{BAP}$ $(\mathrm{mg} / \mathrm{l})$ and in $0.1 \mathrm{NAA}+0.1 \mathrm{BAP}(\mathrm{mg} / \mathrm{l})$ combinations. Lesser degrees of interactions were observed for 'Albescens' in $0 \mathrm{NAA}+0.1 \mathrm{BAP}(\mathrm{mg} / \mathrm{l})$; > 'Nigrescens' in $0.1 \mathrm{NAA}+$ $0.05 \mathrm{BAP}(\mathrm{mg} / \mathrm{l})$; > 'Albescens' in 0 NAA + $0 \mathrm{BAP}(\mathrm{mg} / \mathrm{l})$ $>$ 'Idolatrica' in $0 \mathrm{NAA}+0 \mathrm{BAP}(\mathrm{mg} / \mathrm{l})$; > 'Albescens' in $0.1 \mathrm{NAA}+0 \mathrm{BAP}(\mathrm{mg} / \mathrm{l})>$ 'Idolatrica' in $0 \mathrm{NAA}+0.1$ $\mathrm{BAP}(\mathrm{mg} / \mathrm{l})>$ 'Virescens' in $0.05 \mathrm{NAA}+0.05 \mathrm{BAP}(\mathrm{mg} / \mathrm{l})$; $>$ 'Idolatrica' in $0.1 \mathrm{NAA}+0.05 \mathrm{BAP}(\mathrm{mg} / \mathrm{l})$; > (the least) 'Albescens' in 0.1 NAA + 0.1 BAP (mg/l). All other interactions were similar in magnitude with the highest and lowest limits.

The effects of growth regulators and type-variety of oil palm on plantlet heights of cultured embryos at $42,56,70$ and $84 \mathrm{DCI}$ is presented in Table 2 . Highly significant $(\mathrm{p}<$ 0.05 ) mean square (variations) were obtained among typevariety on plantlet heights at 42,56 and $84 \mathrm{DCI}$, but not at 70 DCI.

Table 1. Effects of growth regulators and type-variety of oil palm on the time of root production, root length at 14, 21, 28 and 35 days after culture initiation

\begin{tabular}{|c|c|c|c|c|c|c|}
\hline \multicolumn{2}{|c|}{ Growth regulators } & \multirow{2}{*}{$\begin{array}{c}\text { Time of root } \\
\text { production }(\mathrm{DCI})\end{array}$} & \multirow{2}{*}{$\begin{array}{c}\text { Root length at } \\
14 \text { days }(\mathrm{cm})\end{array}$} & \multirow{2}{*}{$\begin{array}{l}\text { Root length at } \\
21 \text { days }(\mathrm{cm})\end{array}$} & \multirow{2}{*}{$\begin{array}{l}\text { Root length at } \\
28 \text { days }(\mathrm{cm})\end{array}$} & \multirow{2}{*}{$\begin{array}{l}\text { Root length at } \\
35 \text { days }(\mathrm{cm})\end{array}$} \\
\hline NAA (mg/l) & $\mathrm{BAP}(\mathrm{mg} / \mathrm{l})$ & & & & & \\
\hline 0 & \multirow{3}{*}{0} & $7.31^{b}$ & $0.53^{\mathrm{a}}$ & $1.58^{\mathrm{a}}$ & $2.26^{\mathrm{a}}$ & $4.24^{\mathrm{ab}}$ \\
\hline 0.05 & & $7.81^{\mathrm{ab}}$ & $0.58^{\mathrm{a}}$ & $1.46^{\mathrm{a}}$ & $2.10^{\mathrm{a}}$ & $4.34^{\mathrm{ab}}$ \\
\hline 0.1 & & $8.75^{a}$ & $0.50^{\mathrm{a}}$ & $1.63^{\mathrm{a}}$ & $2.34^{\mathrm{a}}$ & $4.33^{\mathrm{ab}}$ \\
\hline 0 & \multirow{3}{*}{0.05} & $7.31^{\mathrm{b}}$ & $0.57^{\mathrm{a}}$ & $1.71^{\mathrm{a}}$ & $2.41^{\mathrm{a}}$ & $4.78^{a}$ \\
\hline 0.05 & & $7.94^{\mathrm{ab}}$ & $0.48^{\mathrm{a}}$ & $1.81^{\mathrm{a}}$ & $2.49^{\mathrm{a}}$ & $4.42^{\mathrm{ab}}$ \\
\hline 0.1 & & $8.69^{\mathrm{a}}$ & $0.47^{\mathrm{a}}$ & $1.33^{\mathrm{b}}$ & $2.48^{\mathrm{a}}$ & $4.24^{\mathrm{ab}}$ \\
\hline 0 & \multirow{3}{*}{0.1} & $8.19^{\mathrm{ab}}$ & $0.51^{\mathrm{a}}$ & $1.63^{\mathrm{a}}$ & $2.41^{a}$ & $4.18^{\mathrm{b}}$ \\
\hline 0.05 & & $8.00^{\mathrm{a}}$ & $0.60^{\mathrm{a}}$ & $1.19^{\mathrm{a}}$ & $2.43^{\mathrm{a}}$ & $4.49^{\mathrm{ab}}$ \\
\hline 0.1 & & $8.88^{\mathrm{a}}$ & $0.48^{\mathrm{a}}$ & $1.62^{\mathrm{a}}$ & $2.33^{\mathrm{a}}$ & $4.19^{\mathrm{b}}$ \\
\hline \multicolumn{2}{|c|}{ SED } & 0.426 & 0.077 & 0.172 & 0.146 & 0.187 \\
\hline \multicolumn{2}{|c|}{ Significance } & $* * *$ & ns & ns & ns & ${ }^{*}$ \\
\hline \multicolumn{7}{|c|}{ Type-variety } \\
\hline \multicolumn{2}{|c|}{ 'Albescens' } & $8.06^{\mathrm{a}}$ & $0.54^{a}$ & $1.54^{\mathrm{b}}$ & $2.24^{b}$ & $4.22^{\mathrm{b}}$ \\
\hline \multicolumn{2}{|c|}{ 'Nigrescens' } & $8.06^{\mathrm{a}}$ & $0.53^{\mathrm{a}}$ & $1.83^{\mathrm{a}}$ & $2.50^{\mathrm{a}}$ & $4.62^{\mathrm{a}}$ \\
\hline \multicolumn{2}{|c|}{ 'Virescens' } & $8.08^{\mathrm{a}}$ & $0.48^{\mathrm{a}}$ & $1.66^{\mathrm{ab}}$ & $2.39^{\mathrm{ab}}$ & $4.44^{\mathrm{ab}}$ \\
\hline \multicolumn{2}{|c|}{ 'Idolatrica' } & $8.19^{\mathrm{a}}$ & $0.54^{a}$ & $1.52^{\mathrm{b}}$ & $2.30^{\mathrm{ab}}$ & $4.29^{\mathrm{b}}$ \\
\hline \multicolumn{2}{|c|}{ SED } & 0.284 & 0.052 & 0.115 & 0.097 & 0.124 \\
\hline \multicolumn{2}{|c|}{ Significance } & ns & ns & * & $*$ & * \\
\hline \multicolumn{2}{|c|}{ Interactions } & ns & ns & ns & $\mathrm{ns}$ & $* * *$ \\
\hline \multicolumn{2}{|c|}{ SED } & 0.853 & 0.154 & 0.344 & 0.292 & 0.373 \\
\hline
\end{tabular}

${ }^{*},{ }^{* *},{ }^{* * *}$ Significant at $0.05,0.01,0.001$ probability levels respectively; $\mathrm{n} s=$ not significant

Means with the same alphabet are not significantly different at 0.05 probability level; DCI: Days after culture initiation 


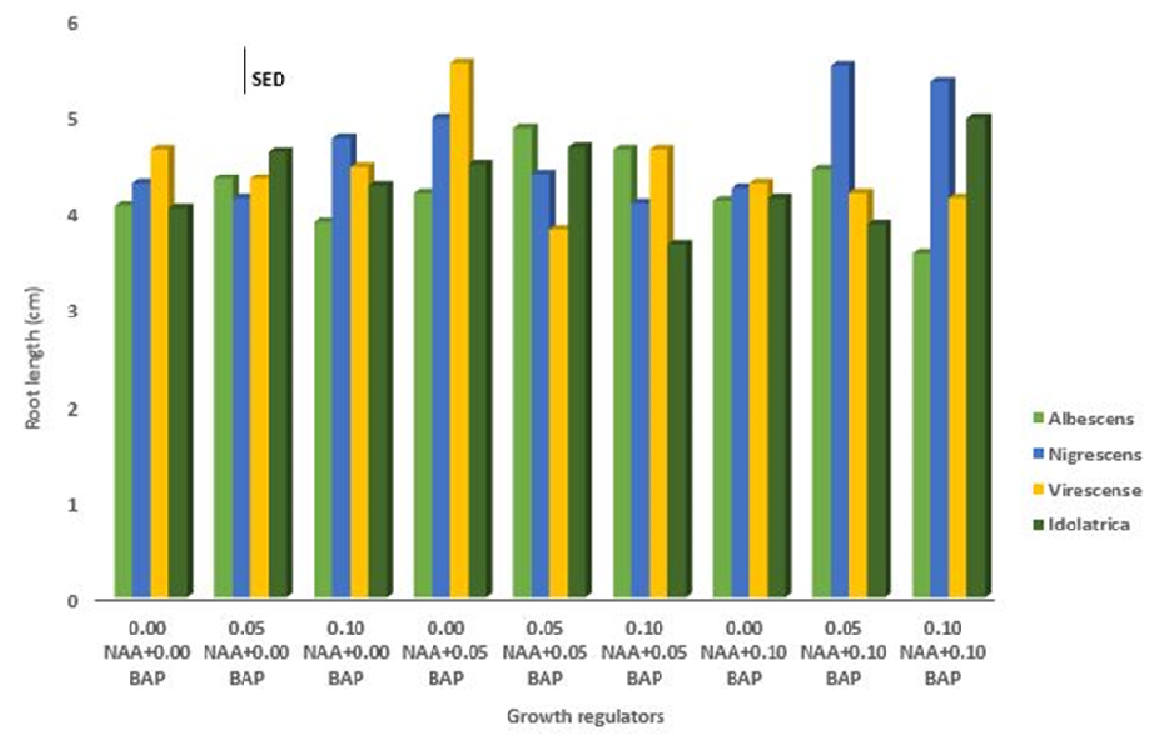

Fig. 1. Interaction effect of growth regulators and type-variety of oil palm on root length at 35 days after culture initiation

The tallest plantlets across the sampling times $(42,56$, 70 and 84 DCI) were the 'Idolatrica', followed by the 'Virescens'. They were however not significantly $(\mathrm{p}<0.05)$ different from each other, except at $70 \mathrm{DCI}$, where the 'Idolarica' were the shortest along with 'Albescens'. 'Albescens' and 'Nigrescens' had significantly $(\mathrm{p}<0.05)$ shorter plantlets than 'Virescens' and 'Idolatrica' at 42 and 84 DCI, respectively. The influence of growth regulators' combinations and their varied concentrations on plantlet heights of cultured embryos did not vary at 42 and 84 DCI, but significantly $(\mathrm{p}<0.05)$ differed at 56 and 70 DCI (Table 2). At 56 DCI, the highest mean value (13.33 $\mathrm{cm})$ for plantlet height was recorded from medium which contained $0.05 \mathrm{NAA}+0.05 \mathrm{BAP}(\mathrm{mg} / \mathrm{l})$ and the least mean value $(11.94 \mathrm{~cm})$ was obtained from medium having 0.1 $\mathrm{NAA}+0 \mathrm{BAP}(\mathrm{mg} / \mathrm{l})$. These values varied significantly. At $70 \mathrm{DCI}$, the highest mean value $(17.95 \mathrm{~cm})$ for plantlet heights was obtained from the medium containing 0.05 $\mathrm{NAA}+0.1 \mathrm{BAP}(\mathrm{mg} / \mathrm{l})$, while the lowest mean value $(16.45 \mathrm{~cm})$ was from medium supplemented with $0.1 \mathrm{NAA}$ +0.05 BAP $(\mathrm{mg} / \mathrm{l})$. Both values differed significantly $(\mathrm{p}<$ 0.05 ). All other combinations were similar and did not differ significantly from the two extreme mean values.

Table 2. Effects of growth regulators and type-variety of oil palm on plantlet heights at 42, 56, 70 and 84 days after culture initiation

\begin{tabular}{|c|c|c|c|c|c|}
\hline \multicolumn{2}{|c|}{ Growth regulators } & \multirow{2}{*}{$\begin{array}{c}\text { Plantlet height at } \\
42 \text { days }(\mathrm{cm})\end{array}$} & \multirow{2}{*}{$\begin{array}{c}\text { Plantlet height at } \\
56 \text { days }(\mathrm{cm})\end{array}$} & \multirow{2}{*}{$\begin{array}{c}\text { Plantlet height at } \\
70 \text { days }(\mathrm{cm})\end{array}$} & \multirow{2}{*}{$\begin{array}{c}\text { Plantlet height at } \\
84 \text { days }(\mathrm{cm})\end{array}$} \\
\hline NAA (mg/l) & $\mathrm{BAP}(\mathrm{mg} / \mathrm{l})$ & & & & \\
\hline 0 & & $7.49^{\mathrm{a}}$ & $12.08^{\mathrm{ab}}$ & $16.65^{\mathrm{ab}}$ & $20.58^{a}$ \\
\hline 0.05 & \multirow[t]{2}{*}{0} & $7.35^{\mathrm{a}}$ & $12.66^{\mathrm{ab}}$ & $17.66^{\mathrm{ab}}$ & $19.18^{\mathrm{a}}$ \\
\hline 0.1 & & $7.81^{\mathrm{a}}$ & $11.94^{\mathrm{b}}$ & $17.29^{\mathrm{ab}}$ & $19.91^{\mathrm{a}}$ \\
\hline 0 & \multirow{4}{*}{0.05} & $7.86^{\mathrm{a}}$ & $12.67^{\mathrm{ab}}$ & $16.79^{\mathrm{ab}}$ & $20.46^{\mathrm{a}}$ \\
\hline 0.05 & & $7.68^{\mathrm{a}}$ & $13.33^{\mathrm{a}}$ & $17.16^{\mathrm{ab}}$ & $20.29^{\mathrm{a}}$ \\
\hline 0.1 & & $7.21^{\mathrm{a}}$ & $12.34^{\mathrm{ab}}$ & $16.45^{\mathrm{b}}$ & $20.14^{a}$ \\
\hline 0 & & $7.86^{\mathrm{a}}$ & $12.69^{\mathrm{ab}}$ & $17.14^{\mathrm{ab}}$ & $19.66^{a}$ \\
\hline 0.05 & \multirow[t]{2}{*}{0.1} & $7.59^{\mathrm{a}}$ & $12.71^{\mathrm{ab}}$ & $17.95^{\mathrm{a}}$ & $20.64^{a}$ \\
\hline 0.1 & & $7.29^{\mathrm{a}}$ & $12.27^{\mathrm{ab}}$ & $17.30^{\mathrm{ab}}$ & $20.16^{\mathrm{a}}$ \\
\hline \multicolumn{2}{|c|}{ SED } & 0.267 & 0.407 & 0.441 & 0.577 \\
\hline \multicolumn{2}{|c|}{ Significance } & ns & * & * & ns \\
\hline \multicolumn{6}{|c|}{ Type-variety } \\
\hline \multicolumn{2}{|c|}{ 'Albescens' } & $7.16^{b}$ & $12.02^{c}$ & $17.00^{\mathrm{a}}$ & $19.34^{\mathrm{b}}$ \\
\hline \multicolumn{2}{|c|}{ 'Nigrescens' } & $7.21^{\mathrm{b}}$ & $12.72^{b}$ & $17.12^{\mathrm{a}}$ & $18.59^{\mathrm{b}}$ \\
\hline \multicolumn{2}{|c|}{ 'Virescens' } & $7.88^{\mathrm{a}}$ & $12.04^{\mathrm{c}}$ & $17.48^{\mathrm{a}}$ & $21.07^{a}$ \\
\hline \multicolumn{2}{|c|}{ 'Idolatrica' } & $8.04^{\mathrm{a}}$ & $13.32^{\mathrm{a}}$ & $17.01^{\mathrm{a}}$ & $21.46^{\mathrm{a}}$ \\
\hline \multicolumn{2}{|c|}{ SED } & 0.178 & 0.271 & 0.294 & 0.384 \\
\hline \multicolumn{2}{|c|}{ Significance } & $* * *$ & $* * *$ & ns & $* * *$ \\
\hline \multicolumn{2}{|c|}{ Interactions } & ns & ** & ns & ** \\
\hline \multicolumn{2}{|c|}{ SED } & 0.534 & 0.814 & 0.883 & 1.153 \\
\hline
\end{tabular}

${ }^{*}, * *{ }^{* * *}$ Significant at $0.05,0.01,0.001$ probability levels respectively; $\mathrm{ns}=$ not significant

Means with the same alphabet are not significantly different at 0.05 probability level 
The interaction variances were highly significant $(\mathrm{p}<$ 0.01 ) at 56 and 84 DCI only (Table 2) and are presented as Fig. $2 \mathrm{a}$ and $2 \mathrm{~b}$, respectively. At $56 \mathrm{DCI}$, the highest type-variety $\mathrm{x}$ growth regulators effect on plantlet heights was obtained from 'Idolatrica' in $0.05 \mathrm{NAA}+0.05 \mathrm{BAP}$ $\mathrm{mg} / \mathrm{l}$, followed by 'Idolatrica' in $0.05 \mathrm{NAA}+0.1 \mathrm{BAP}$ $\mathrm{mg} / \mathrm{l}$, while the least effects were from 'Albescens' in 0.1 $\mathrm{NAA}+0.1 \mathrm{BAP}$ mg/l; 'Albescens' in $0 \mathrm{NAA}+0.05 \mathrm{BAP}$ $\mathrm{mg} / \mathrm{l}$; 'Albescens' in $0.1 \mathrm{NAA}+0 \mathrm{BAP} \mathrm{mg} / \mathrm{l}$; 'Virescens' in $0 \mathrm{NAA}+0.1 \mathrm{BAP} \mathrm{mg} / \mathrm{l}$; and 'Virescens' in $0 \mathrm{NAA}+0$ BAP mg/l. The highest interaction effects at $84 \mathrm{DCI}$ was 'Virescens' in $0 \mathrm{NAA}+0.05 \mathrm{BAP} \mathrm{mg} / \mathrm{l}$ and followed by 'Idolatrica' in $0.05 \mathrm{NAA}+0.1 \mathrm{BAP} \mathrm{mg} / \mathrm{l}$, while the least were 'Nigrescens' in $0 \mathrm{NAA}+0.05 \mathrm{BAP} \mathrm{mg} / \mathrm{l}$ and 'Nigrescens' in $0.05 \mathrm{NAA}+0 \mathrm{BAP} \mathrm{mg} / \mathrm{l}$.

Table 3 shows the results obtained for the number of leaves and roots of plantlets produced by in vitro seed embryos of type-variety of oil palm at $84 \mathrm{DCI}$ in culture media supplemented with different combinations of growth regulators. There were no significant variations among the type-variety on the number of leaves and roots produced at 84 DCI. Significant variations $(p<0.05)$ were observed due to growth regulators on number of leaves, but nonsignificant for number of roots. The highest and significantly different mean value (2.56) for number of leaves was from the medium supplemented with 0.1 NAA + $0 \mathrm{BAP} \mathrm{mg} / \mathrm{l}$, while the least mean number of leaves (1.69) were recorded from the medium supplemented with 0 $\mathrm{NAA}+0.1 \mathrm{BAP} \mathrm{mg} / \mathrm{l}$ and $0.05 \mathrm{NAA}+0.1 \mathrm{BAP} \mathrm{mg} / \mathrm{l}$.

The type-variety $\times$ growth regulators variance was however non-significant on the number of leaves and roots of the plantlets developed. Plantlets generated from the embryos of the four type-varieties are shown in Fig. 3.
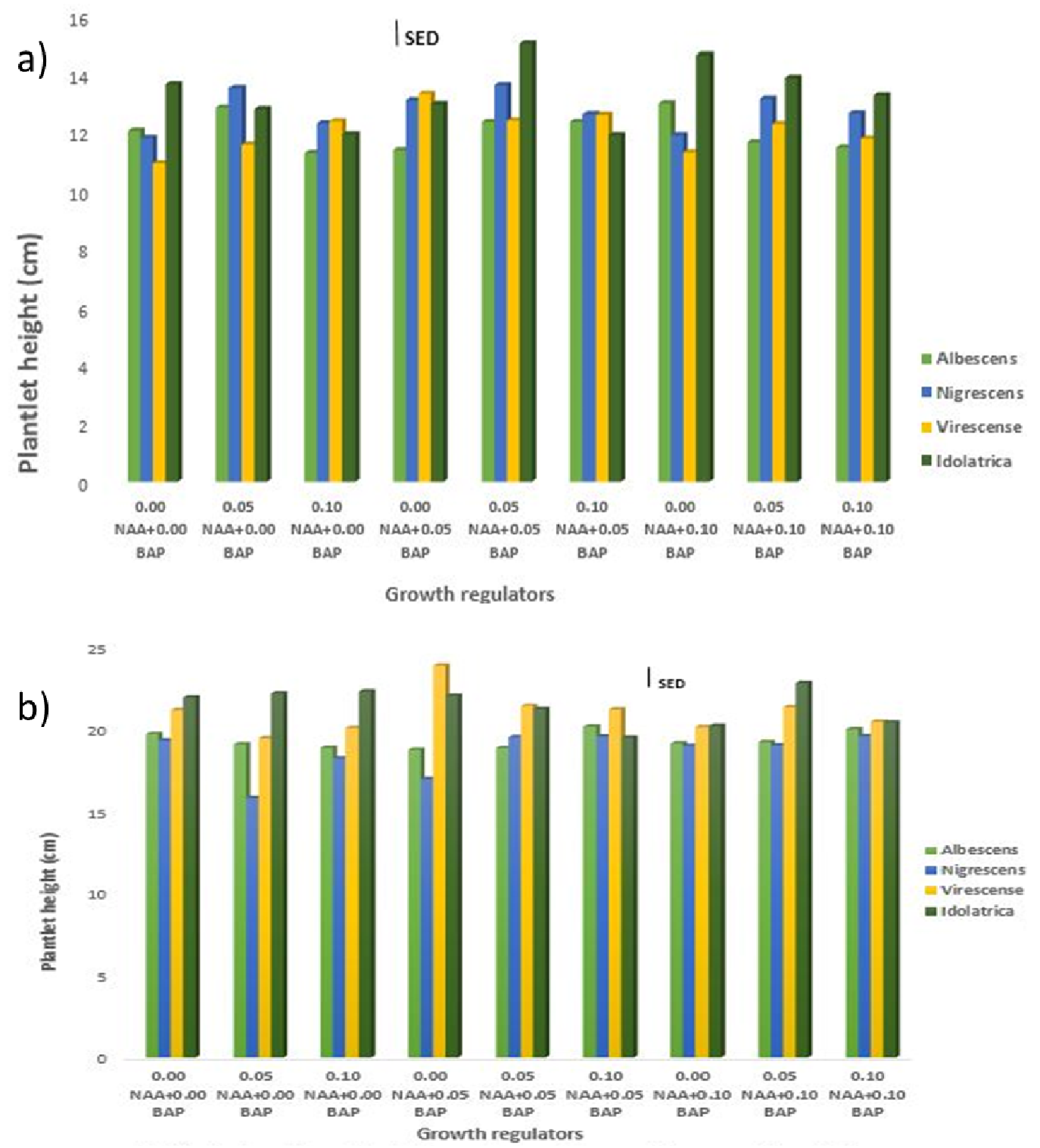

Fig. 2a. Interaction effect of growth regulators and type-variety of oil palm on plantlet height at 56 days after culture initiation Fig. 2b. Interaction effect of growth regulators and type-variety of oil palm on plantlet height at 84 days after culture initiation 
Table 3. Effects of growth regulators and type-variety of oil palm on the number of leaves and roots at 84 days after culture initiation

\begin{tabular}{|c|c|c|c|}
\hline \multicolumn{2}{|c|}{ Growth regulators } & \multirow{2}{*}{$\begin{array}{l}\text { No. of leaves } 84 \text { days after culture initiation } \\
\qquad(\mathrm{cm})\end{array}$} & \multirow{2}{*}{$\begin{array}{l}\text { No. of roots } 84 \text { days after culture initiation } \\
\qquad(\mathrm{cm})\end{array}$} \\
\hline $\mathrm{NAA}(\mathrm{mg} / \mathrm{l})$ & $\mathrm{BAP}(\mathrm{mg} / \mathrm{l})$ & & \\
\hline 0 & & $1.88^{\mathrm{ab}}$ & $6.12^{\mathrm{a}}$ \\
\hline 0.05 & \multirow[t]{2}{*}{0} & $2.06^{\mathrm{ab}}$ & $6.31^{2}$ \\
\hline 0.1 & & $2.56^{2}$ & $6.56^{2}$ \\
\hline 0 & \multirow{4}{*}{0.05} & $2.38^{\mathrm{ab}}$ & $5.94^{a}$ \\
\hline 0.05 & & $2.31^{\mathrm{ab}}$ & $6.75^{\mathrm{a}}$ \\
\hline 0.1 & & $2.50^{\mathrm{a}}$ & $5.56^{\mathrm{a}}$ \\
\hline 0 & & $1.69^{\mathrm{b}}$ & $5.00^{2}$ \\
\hline 0.05 & \multirow[t]{2}{*}{0.1} & $1.69^{\mathrm{b}}$ & $6.00^{2}$ \\
\hline 0.1 & & $2.00^{\mathrm{ab}}$ & $5.94^{a}$ \\
\hline \multicolumn{2}{|c|}{ SED } & 0.248 & 0.669 \\
\hline \multicolumn{2}{|c|}{ Significance } & $* * *$ & ns \\
\hline \multicolumn{4}{|c|}{ Type-variety } \\
\hline \multicolumn{2}{|c|}{ 'Albescens' } & $2.11^{a}$ & $6.11^{\mathrm{a}}$ \\
\hline \multicolumn{2}{|c|}{ 'Nigrescens' } & $1.92^{\mathrm{a}}$ & $5.86^{a}$ \\
\hline \multicolumn{2}{|c|}{ 'Virescens' } & $2.17^{\mathrm{a}}$ & $6.28^{\mathrm{a}}$ \\
\hline \multicolumn{2}{|c|}{ 'Idolatrica' } & $2.28^{\mathrm{a}}$ & $5.83^{\mathrm{a}}$ \\
\hline \multicolumn{2}{|c|}{ SED } & 0.165 & 0.446 \\
\hline \multicolumn{2}{|c|}{ Significance } & ns & ns \\
\hline \multicolumn{2}{|c|}{ Interactions } & ns & ns \\
\hline \multicolumn{2}{|c|}{ SED } & 0.496 & 1.338 \\
\hline
\end{tabular}

${ }^{*}{ }^{* *},{ }^{* * *}$ Significant at $0.05,0.01,0.001$ probability levels respectively; ns = not significant

Means with the same alphabet are not significantly different at 0.05 probability level

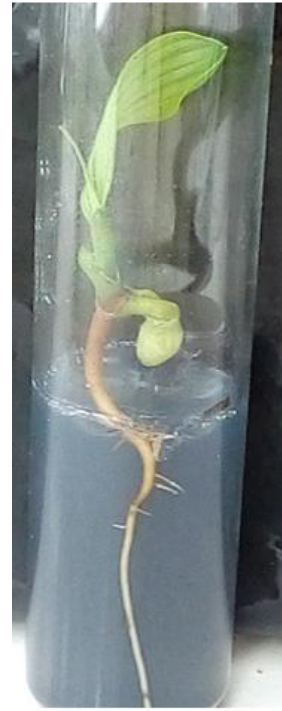

a

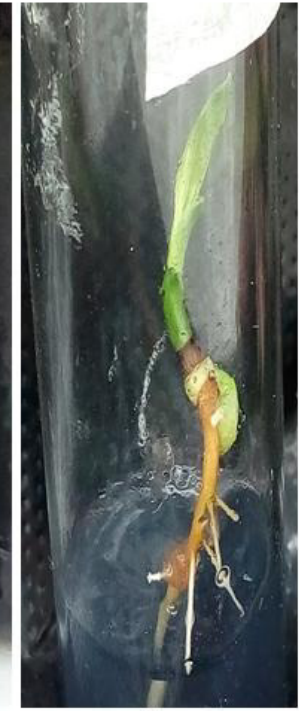

b

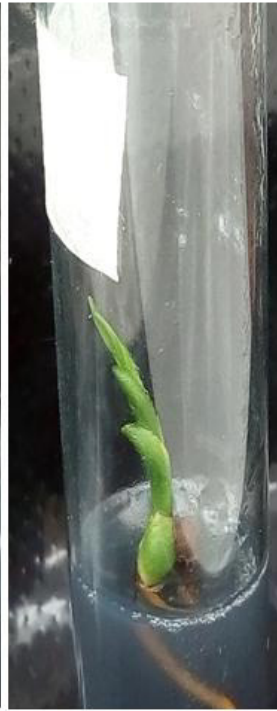

C

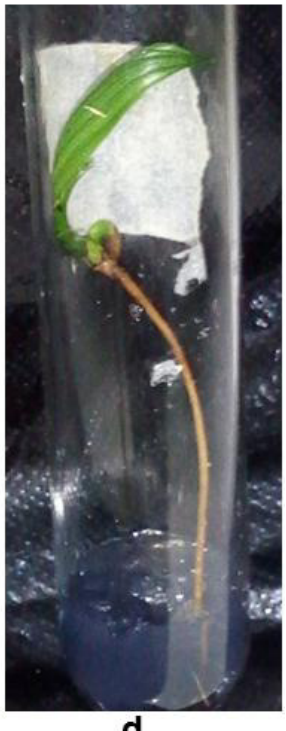

d

Fig. 3. Plantlets generated 84 days after culture initiation of type-variety of oil palm; (a) 'Idolatrica'; (b) 'Albescens'; (c) 'Nigrescens'; (d) 'Virescens'

\section{Discussion}

In order to investigate the main effects of type-variety ('Albescens', 'Nigrescens', 'Virescens' and 'Idolatrica) and growth regulators (NAA and BAP) and their interactions on direct organogenesis of oil palm, in vitro embryo cultures were established. Data on the time of root production, root length at different time intervals, plantlet height, number of leaves and number of roots were obtained. The interaction of auxin and cytokinin in in vitro cultures plays a vital role in cell division, growth development, differentiation and formation of plant organs (Shrivastava and Benerjee, 2008; Purkayastha et al., 2010). In the present study, the pattern of development and morphogenesis (i.e. swelling and expansion of zygotic embryo, emergence of roots and shoot, and regeneration of whole plants) of type-variety in response to the growth regulators were observed.

Regeneration of whole plantlet was observed approximately $35 \mathrm{DCI}$ and was similar to the pattern reported by Thawaro and Te-chato (2010). They reported that swelling of zygotic embryo of Elaeis guineensis Jacq. 
Tenera fruit form occurred at $10 \mathrm{DCI}$, followed by initiation of shoots at $14 \mathrm{DCI}$ and development of complete plantlet after one month.

The results of this study showed that the responses of the various types of oil palm embryos of 'Albescens', 'Nigrescens', 'Virescens' and 'Idolatrica' type-variety in the generation of plantlet varied with respect to media supplementation and it was observed that low concentration of auxins (NAA) and cytokinin (BAP) alone and in combination, yielded shoot, root and plantlet in Murashige and Skoog's medium. Significant differences were observed among the growth regulator treatment combinations but there were no significant differences among the type-variety and their interactions on the time of root production, however earliest root production was attained in 7.31 days in MS medium supplemented with 0 $\mathrm{NAA}+0.05 \mathrm{BAP} \mathrm{mg} / \mathrm{l}$ by 'Albescens' type. The maximum length of root was $2.49 \mathrm{~cm}$ in MS medium supplemented with $0.05 \mathrm{NAA}+0.05 \mathrm{BAP}(\mathrm{mg} / \mathrm{l})$ at 28 days after inoculation. This observation was similar to Periasamy et al. (2003), where after one month the highest root length recorded was $1.63 \mathrm{~cm}$. The extensive growth of root in 0.05 $\mathrm{NAA}+0.05$ BAP $(\mathrm{mg} / \mathrm{l})$ medium might be due to synergistic effect of activated charcoal and plant growth regulators, especially NAA which stimulates the production of roots. It seemed that low concentration of auxin and cytokinin combination is effectual for root induction from oil palm. Root production using a combination of auxin and cytokinin has also been reported by Dixon (1985). This observation is in line with Dixon (1985) who reported that suitable high level of auxin combined with low amount of cytokinin promotes root initiation. Inducing effects of NAA with BAP was also reported by Gantait et al. (2008) where MS medium fortified with a low level of NAA and BAP promoted earliest root initiation in Gerbera.

In the present study, all media supplemented with or without plant growth regulators were able to induce plantlets. This observation indicated that there might be some endogenous growth regulators that may promote germination of the type-variety of oil palm and the differences observed may be due to synergy of exogenous and endogenous growth factors. The height of the plantlet was measured at $42,54,70$ and 84 days after inoculation, the maximum height of plantlet at 84 days which was 20.64 $\mathrm{cm}$ was obtained in MS medium fortified with $0.05 \mathrm{NAA}+$ $0.1 \mathrm{BAP}(\mathrm{mg} / \mathrm{l})$. This was not in line with Ezeibekwe et al., (2009) where the control, 0 BAP + 0 NAA (mg/l) had the tallest plantlet when Dioscorea rotundata L (White yam) was cultured. However, the result of the study was in conformity with Lakshmi et al. (2006) where the growth and morphogenetic responses of in vitro culture was dependent among other factors on the correct constituents and balance of plant growth regulators used.

The results of this study showed that the type-variety and treatment combinations affected the number of leaflet significantly at 84 days as well as the interaction effects. For number of roots, the type-variety and interaction were not significantly different from each other but there were significant differences among the growth regulators. However, the highest number of roots $(6.75 \mathrm{~cm})$ was obtained from 'Virescen's' cultured in MS fortified with 0.1 $\mathrm{NAA}+0.05$ BAP $(\mathrm{mg} / \mathrm{l})$, while for number of roots
'Idolatrica' type-variety had the highest in MS medium supplemented with $0 \mathrm{NAA}+0.1 \mathrm{BAP} \mathrm{mg} / \mathrm{l}$. It was also most vigorous in growth compared to other types; 'Albescens, 'Virescens' and 'Nigrescens'.

\section{Conclusions}

The different concentrations of Naphthalene acetic acid (NAA) and 6-Benzylamino purine (BAP) used in the present study showed that the various type-variety responded differently to them. That be the case, the interaction effects which showed the varied responses of the type-variety to specific and respective combinations of the two growth regulators used should serve as best guide on the concentrations of the combinations to be used for the respective type-variety in vitro embryogenesis /organogenesis. All the same, oil palm seedling development can be improved by using the range of low concentrations of the growth regulators deployed in this study and 0.05 NAA $+0.1 \mathrm{BAP}(\mathrm{mg} / \mathrm{l})$ in particular being the concentration combination that gave the best result.

\section{Acknowledgements}

The present research received no specific grant from any funding agency in the public, commercial, or not-for-profit sectors.

\section{References}

Bailey AE (1933). Industrial oil and fat products. Interscience Publishers Inc, New York 427:153-170.

Caldas LS, Haridasan P, Ferreira ME (1990). Meios nutritivos. In: Torres AC, Caldas LS (Eds). Técnicas e aplicações da cultura de tecidos de plantas. Brasilia: ABCTP/Embrapa-CNPH pp37-70.

Corley HV, Tinker PB (2003). The oil palm (4th ed). Blackwell Publishing Company, UK.

Dixon RA (1985). Plant cell culture: A practical approach. IRL Press Ltd, Oxford.

Ezeibekwe IO, Ezenwaka CL, Mbagwu FN, Unamba CIN (2009). Effects of combination of different levels of auxin (NAA) and cytokinin (BAP) on in vitro propagation of Dioscorea Rotundata L. (White Yam). New YorkScience Journal 2(5):1-8.

Gantait S, Mandal N, Bhattacharyya S, Das PK (2008). In vitro mass multiplication with pure genetic identity in Anthurium andreanum Lind. Plant Tissue Culture and Biotechnology 18:113-122.

Hussain A, Naz S, Nazir H, Shinwari ZK (2011). Tissue culture of black pepper (Piper nigrum L.) in Pakistan. Pakistan Journal of Botany 43(2):1069-1078.

Lakshmi S, Bammi RK, Randawa GS (2006). Clonal propagation of Dioscorea floribunda by tissue culture. Journal of Horticultural Science 51:551-554.

Mgbeze GC, Iserhienrhien A (2013). Somaclonal variation associated with oil palm (Elaeis guineensis Jacq.) clonal propagation. African Journals of Biotechnology 120:20-26.

Murashige T, Skoog F (1962). A revised medium for rapid growth and 
258

bioassays with tobacco tissue cultures. Physiologia Plantarum 15:473497.

Ndon BA (2006). The oil palm. Concept Publication Limited, Lagos, Nigeria.

Nwankwo BA, Krikorian AD (1983). Morphogenetic potential of embryo and seedling derived callus of Elaeis guineensis Jacq. variety. 'pisifera' Becc. Annals of Botany 51:65-76.

Odenore VD, Eke CR, Asemota O, Shittu HO (2015). Determination of phylogenetic relationship among oil palm (Elaeis guineensis) varieties with random amplified polymorphic DNA. European International Journal of Science and Technology 4(2):155-160.

Odewale JO (1983). Development of tissue culture techniques and callus induction in the Oil palm (Elaeis guineensis Jacq.) anthers. PhD Thesis, University of Ife, Nigeria.

Opeke LK (1992). Tropical tree crops. Spectrum Books Limited, Jersey, UK.

Periasamy S, Uma RS, Subramaniam S, Maheran AA, Nordin R, Gantait S (2003). Effect of plant growth regulators and activated charcoal on in vitro growth and development of oil palm (Elaeis guineensis Jacq. var. 'Dura') zygotic. African Journals of Biotechnology 10:82-90.

Pierik RIM (1984). In vitro culture of higher plants: International course on applied plant breeding. International Agricultural Centre, Wageningen, TheNetherlands.

Purkayastha J, Sugla T, Paul A, Solleti SK, Mazumdar P, Basu A, Mohommad A, Ahmed Z, Sahoo L (2010). Efficient in vitro plant regeneration from shoot apices and gene transfer by particle bombardment in Jatropha curcas. Biologia Plantarum 54(1):13-20.
Rival AR (2000). Some factors affecting the viability of oil palm seeds in storage. Journal of the Nigerian Institute for Oil Palm Research 4:317323.

Seng TY, Faridah QZ, Ho CL, Maizura I, Vengeta R (2007). Flanking AFLP markers for the virescens trait in oil palm: Journal of Oil Palm Research 19:381-392.

Shittu HO, Mgbeze GC (2012). In vitro responses of oil palm (Elaeis guineensis, Jacq) embryo axes culture. African Scientist 13:127-133.

Shittu HO, Mgbeze GC, Okoloko GE, Asemota EO, Eke CR (2013). In vitro assessment of embryo age and Naphthalene acetic acid supplementation of media in callus generation of oil palm (Elaeis guineensis Jacq). Nigerian Journal of Life Sciences 3(1):178-185.

Shittu HO, MgbezeGC,EkeCR, Asemota O (2015). Explant age, auxin concentrations and media type affect callus production from oil palm (Elaeis guineensis) embryo axes. NISEB Journal 15(2):38-43.

Shrivastava S, Banerjee M (2008). In vitro clonal propagation of physic nut (Jatropha curcas L.): Influence of additives. International Journal of Integrative of Biology 3:73-79.

ThawaroS, Te-chatoS (2010). Auxins as an effective type of callus formation for mature zygotic embryo culture of hybrid oil palms. International Conference on Integration of Science and Technology for Sustainable Development, Bangkok pp 246-250.

Trejgell A, Tretyn A, Nicos D (1998). Attempt at regeneration of Pharbitis nil from fragments of vegetative organs. Physiologia Plantarum 20:161166. 